\title{
Responses of marine macroalgae to hydrogen-peroxide stress
}

\author{
A.L. Dummermuth ${ }^{\mathrm{a}, *}$, U. Karsten ${ }^{\mathrm{b}}$, K.M. Fisch ${ }^{\mathrm{c}}$, \\ G.M. König ${ }^{\mathrm{c}}$, C. Wiencke ${ }^{\mathrm{a}}$ \\ ${ }^{a}$ Alfred Wegener Institute for Polar and Marine Research, Am Handelshafen 12, D-27570, \\ Bremerhaven, Germany \\ ${ }^{\mathrm{b}}$ University of Rostock, Institute of Aquatic Ecology, Albert-Einstein-Str. 3 D-18051, Rostock, Germany \\ ${ }^{\mathrm{c}}$ University of Bonn, Institute for Pharmaceutical Biology, Nussallee 6, D-53115, Bonn, Germany
}

Received 11 August 2002; received in revised form 19 December 2002; accepted 19 January 2003

\begin{abstract}
In this study, we determined the antioxidative potential of 15 marine macroalgae by measuring the photosynthetic efficiency under artificial oxidative stress after a 30-min exposure to a series of ascending $\mathrm{H}_{2} \mathrm{O}_{2}$ concentrations. Species exhibiting high maximum quantum yields $\left(F_{\mathrm{v}} / F_{\mathrm{m}}\right.$ values $)$ were regarded as not susceptible towards $\mathrm{H}_{2} \mathrm{O}_{2}$ stress. In addition to the short-term stress experiments, the antioxidative defense systems (enzymatic and non-enzymatic) of selected algal species under longer exposure times to $\mathrm{H}_{2} \mathrm{O}_{2}$ were investigated.

Species with striking photosynthetic activity under $\mathrm{H}_{2} \mathrm{O}_{2}$ stress were Chaetomorpha melagonium (Chlorophyta), showing $40 \%$ reduced $F_{\mathrm{v}} / F_{\mathrm{m}}$ as compared to the control after 8 days of exposure to $20 \mathrm{mM} \mathrm{H}_{2} \mathrm{O}_{2}$. In Fucus distichus (Phaeophyta) $F_{\mathrm{v}} / F_{\mathrm{m}}$ decreased to $50 \%$ of the control under the same exposure conditions. Polysiphonia arctica (Rhodophyta) exhibited highest $F_{\mathrm{v}} / F_{\mathrm{m}}$ values with a reduction of only $25 \%$, therefore possessing the highest antioxidative potential of the investigated species.
\end{abstract}

Abbreviations: APX, ascorbate peroxidase; BHT, butylated hydroxytoluene; CAT, catalase; DCM, dichloromethane; DPPH, $\alpha, \alpha$-diphenyl- $\beta$-picrylhydrazyl radical; FGM1, degrees of freedom of model 1; FGM2, degrees of freedom of model 2; FGR2, degrees of freedom of residuals of model 2; GC-MS, gas chromatography mass spectrometry; GR, glutathione reductase; MDA, malondialdehyde; MSTFA, $N$-methyl- $N$ trimethylsilyltriflouracetamid; NADPH, nicotinamid adenine dinucleotide phosphate; ROS, reactive oxygen species; SAQM1, sum of squares of model 1; SAQM2, sum of squares of model 2; SAQR2, sum of squares of residuals of model 2; SOD, superoxide dismutase; TBA, thiobarbituric acid; TBARS, thiobarbituric acid reactive substances; TMS, tetramethylsilan; TSP, total soluble protein.

* Corresponding author. Tel.: +49-471-4831-1540; fax: +49-47148311425.

E-mail address: adummermuth@awi-bremerhaven.de (A.L. Dummermuth). 
In $P$. arctica the activities of the antioxidative enzymes superoxide dismutase (SOD), catalase (CAT), ascorbate peroxidase (APX) and glutathione reductase (GR), as well as the pool size of the antioxidant ascorbic acid were investigated. When exposed to different $\mathrm{H}_{2} \mathrm{O}_{2}$ concentrations $(0-2$ $\mathrm{mM}$ ) over 6 days, the intrinsic activities of SOD and GR were stimulated. In a kinetic study over 8 days, the activity of antioxidative enzymes APX and CAT as well as ascorbic acid content were recorded. APX activity was much higher in $\mathrm{H}_{2} \mathrm{O}_{2}$-treated thalli at the end of the experiment than in the control, also CAT activity increased significantly with increasing $\mathrm{H}_{2} \mathrm{O}_{2}$ stress. In parallel, ascorbic acid content was reduced under high $\mathrm{H}_{2} \mathrm{O}_{2}$ concentrations. Furthermore, by using $\mathrm{GC}-$ MS techniques in $P$. arctica bromophenolic compounds with antioxidative properties were identified.

This study shows that the measurement of the in vivo fluorescence of photosystem II is a suitable tool to determine the effect of oxidative stress on macroalgae. From these studies it is obvious that different algal species have varying strategies against oxidative stress which correlate with zonation on the shore.

(C) 2003 Elsevier Science B.V. All rights reserved.

Keywords: Antioxidants; Antioxidative potential; Ascorbic acid; Ascorbate peroxidase; Bromophenolic compounds; Catalase; Marine macroalgae

\section{Introduction}

Many metabolic responses in plants induce formation of reactive oxygen species (ROS), especially light-dependent processes such as photosynthesis. The photosynthetic electron transport system is the major source of ROS in plant tissues having the potential to generate singlet oxygen $\left({ }^{1} \mathrm{O}_{2}\right)$ and superoxide $\left(\mathrm{O}_{2}{ }^{-}\right)$(Asada, 1994a,b). Furthermore, in successive reduction of dioxygen $\left(\mathrm{O}_{2}\right)$, hydrogen peroxide $\left(\mathrm{H}_{2} \mathrm{O}_{2}\right)$ and hydroxyl radical $\left(\mathrm{OH}^{*}\right)$ are formed. Hydrogen peroxide is also produced in the pseudocyclic photophosphorylation and Mehler reaction (Collen et al., 1995; Pedersen et al., 1995; Polle, 1996) and under stress in general (Fourcroy, 1999; Schreck et al., 1996). All these ROS, except hydrogen peroxide, are characterized by a short lifetime, as they interact rapidly with either water or cellular components (Asada, 1994a). Hydrogen peroxide itself is not particularly reactive with most biologically important molecules, but it is probably an intracellular precursor for more reactive oxidants as it passes quickly through membranes by diffusion (Apostol et al., 1989). It reduces photosynthesis (e.g. in spinach) (Kaiser, 1976) by inhibiting a number of photosynthetic enzymes (Elstner, 1982, 1987), such as fructose bisphosphatase, ribulose phosphate kinase and ribulose bisphosphate carboxylase/oxygenase (Rubisco) (Kaiser, 1979; Badger et al., 1980; Bischof et al., 2000; Tanaka et al., 1982) and other enzymes such as SOD (Asada et al., 1975; Forti and Gerola, 1977).

Production of ROS especially occurs under stress conditions during exposure to excessive light or UV radiation as well as during desiccation, under nutrient deficiency, exposure to heavy metals, high or low temperatures and temperature changes (McKersie and Lesham, 1994). If accumulation of ROS exceeds the capacity of enzymatic and nonenzymatic antioxidant systems the photosynthetic apparatus is damaged due to destruction of lipids, proteins and nucleic acids, finally leading to cell death (Asada and Takahashi, 1987; Fridovich, 1978; Halliwell and Gutteridge, 1989; Karpinski et al., 1999; Vacha, 
1995). Cellular protection mechanisms against toxic oxygen species are essential for the maintenance of all metabolic processes including photosynthesis (Allen, 1977; Asada and Takahashi, 1987; Elstner, 1982; Halliwell, 1982). Higher plants are well equipped with enzymatic detoxification systems and antioxidants of different chemical groups diminishing oxidative stress by elimination and reduction of the ROS to less toxic and less reactive products (Larson, 1988). SOD catalyses the conversion of $\mathrm{O}_{2}{ }^{-}$to $\mathrm{H}_{2} \mathrm{O}_{2}$ and oxygen. CAT reduces $\mathrm{H}_{2} \mathrm{O}_{2}$ to water and oxygen in two steps. Hydrogen peroxide is also reduced by ascorbate peroxidase (APX) via the ascorbate-glutathione cycle. Ascorbic acid is dehydrated to monodehydroascorbate and dehydroascorbate and recycled to ascorbic acid by monodehydroascorbate reductase and dehydroascorbate reductase. Both enzymes are dependent on $\mathrm{NADPH}+\mathrm{H}^{+}$, the latter enzyme coupled with GR converting oxidized glutathione to reduced glutathione (Elstner, 1982; Halliwell, 1982). APX shows a higher affinity to $\mathrm{H}_{2} \mathrm{O}_{2}$ than CAT and is located in the chloroplasts, CAT is located in peroxisomes (Halliwell and Gutteridge, 1989; Polle, 1996). In addition to proteins with antioxidative properties, phenolic compounds such as flavonoids, coumarins and tocopherols, nitrogen containing compounds including alkaloids, chlorophyll derivates, amino acids and amines as well as other compounds such as carotenoids, ascorbic acid, glutathione and uric acid are powerful antioxidants in plants (Fujimoto et al., 1985; Larson, 1988; Paya et al., 1992; Potterat, 1997).

Ascorbic acid, $\beta$-carotene and $\alpha$-tocopherol are well known antioxidants in marine algae. The activities of antioxidative enzymes and the content of antioxidants in Arctic marine macroalgae was recently studied by (Aguilera et al., 2002a,b) with particular emphasis on photooxidative stress and the activity of these biochemical defense systems against high light and ultraviolet radiation. However, data on further properties of these antioxidative systems in Arctic species, particularly under direct $\mathrm{H}_{2} \mathrm{O}_{2}$ stress, are missing.

The aim of the present study was firstly to determine the antioxidative potential in macroalgae by using a fast assay originally developed by Collen and Pedersen (1996). Species with a high $\mathrm{H}_{2} \mathrm{O}_{2}$ tolerance might be a possible source for antioxidative substances for commercial or pharmaceutical purposes. Secondly, the ability of macroalgae to cope with hydrogen peroxide stress over a longer time period was investigated. Therefore, $P$. arctica was incubated in ascending hydrogen peroxide concentrations over 8 days and enzymatic detoxification systems (SOD, CAT, GR, APX) as well as the antioxidant ascorbic acid were determined. In addition, antioxidative phenolic compounds were isolated from this red alga and characterized by gas chromatography-mass spectrometry (GC-MS) in order to describe the chemical mechanisms responsible for the detected extraordinary high antioxidative potential.

\section{Material and methods}

\subsection{Algal material and study site}

Plants were collected by scuba diving in summer 1999 and summer 2000 at the study site in the Kongsfjord (Ny Ålesund, Spitsbergen, Norway $78^{\circ} 55.5^{\prime} \mathrm{N} ; 1^{\circ} 56.0^{\prime} \mathrm{E}$ ) from 
depths between 0 and $20 \mathrm{~m}$ (Table 1). Algal samples were collected in black bags to avoid exposure to high irradiance and kept in seawater during transport. In the laboratory the plant material was kept at $2-5{ }^{\circ} \mathrm{C}$ for at least $24 \mathrm{~h}$ under dim white fluorescent lamps (Philips $58 \mathrm{~W} / 950$ ) adjusted to $25 \mu \mathrm{mol}$ photons $\mathrm{m}^{-2} \mathrm{~s}^{-1}$ in running seawater pumped directly from the fjord.

\subsection{Assay for the detection of the antioxidative potential}

To determine the antioxidative potential, 3- to $10-\mathrm{cm}-$ long thallus parts were incubated for $30 \mathrm{~min}$ in $50-\mathrm{ml}$ transparent plastic bottles in seawater at about $5{ }^{\circ} \mathrm{C}$ enriched with $\mathrm{H}_{2} \mathrm{O}_{2}$ in concentrations of $0-20 \mathrm{mM}$. During the last $5 \mathrm{~min}$ of the incubation, the algal samples were kept in darkness. Afterwards the photosynthetic capacity was determined by measuring the variable chlorophyll-fluorescence of photosystem II as described below.

Additionally, thalli of $P$. arctica were supplemented for 1 week in 2-1 plastic bottles containing pure seawater (control) or seawater enriched with $\mathrm{H}_{2} \mathrm{O}_{2}$ to reach final concentrations of $0.5,1,2$ and $5 \mathrm{mM}$. The medium was changed daily to keep $\mathrm{H}_{2} \mathrm{O}_{2}$ concentration constant. The algae were illuminated $24 \mathrm{~h}$ with white fluorescent lamps (Philips $58 \mathrm{~W} / 950$ ) at a photon fluence rate of $25 \mu \mathrm{mol} \mathrm{m} \mathrm{m}^{-2} \mathrm{~s}^{-1}$. Samples for the detection of antioxidative activities were taken on days $0,1,2,4,6$ and 8. Samples were put in liquid nitrogen, lyophylized and subsequently stored at $-30{ }^{\circ} \mathrm{C}$ until analysis.

Table 1

Investigated species, their classification in the three main groups of macroalgae and their habitat

\begin{tabular}{|c|c|}
\hline Species & Habitat \\
\hline \multicolumn{2}{|l|}{ Chlorophyta } \\
\hline Acrosiphonia sp. & Eulittoral-upper sublittoral \\
\hline Monostroma aff. arcticum Wittrock & Upper-lower sublittoral \\
\hline Chaetomorpha melagonium (F. Weber et Mohr) Kützing & Upper-lower sublittoral \\
\hline \multicolumn{2}{|l|}{ Rhodophyta } \\
\hline Coccotylus truncatus (Pallas) M.J. Wynne and J.N. Heine & Lower sublittoral \\
\hline Devaleraea ramentacea (L.) Guiry & Eulittoral-lower sublittoral \\
\hline Palmaria palmata (L.) Greville & Upper-lower sublittoral \\
\hline Phycodrys rubens (L.) Batters & Lower sublittoral \\
\hline Odonthalia dentata (L.) Lyngbye & Lower sublittoral \\
\hline Polysiphonia arctica J. Agardh & Lower sublittoral \\
\hline Ptilota gunneri P.C. Silva, Maggs and L.M. Irvine & Lower sublittoral \\
\hline \multicolumn{2}{|l|}{ Phaeophyta } \\
\hline Alaria esculenta (L.) Greville & Upper-lower sublittoral \\
\hline Laminaria digitata (Huds.) Lamouroux & Upper-lower sublittoral \\
\hline Laminaria solidungula J. Agardh & Lower sublittoral \\
\hline Fucus distichus L. & Eulittoral-lower sublittoral \\
\hline Saccorhiza dermatodea (de la Pylaie) J. Agardh & Upper-lower sublittoral \\
\hline
\end{tabular}




\subsection{Photosynthesis measurements}

Photosynthetic efficiency $\left(F_{\mathrm{v}} / F_{\mathrm{m}}\right)$ was determined by measuring the variable chlorophyll-fluorescence of photosystem II (PSII) using a portable pulse amplitude modulated fluorometer (Diving-PAM, Walz, Effeltrich, Germany) as described by Hanelt (1998). $F_{\mathrm{v}} / F_{\mathrm{m}}$ values of all plants acclimated for $24 \mathrm{~h}$ to dim light conditions in the laboratory were characteristic for photosynthetically non-inhibited plants and set to $100 \%$ (=control). All PAM data recorded are expressed in relation to this value. P. arctica exhibited a maximum $F_{\mathrm{v}} / F_{\mathrm{m}}$ value of 0.67 , which is typical for red algae.

\subsection{Activities of antioxidative enzymes}

Samples (0.010-0.012 g DW) were ground in liquid nitrogen and extracted with $1-1.5$ $\mathrm{ml} 50 \mathrm{mM}$ potassium phosphate buffer $\left(\mathrm{pH}\right.$ 7.0) containing Complete $^{\mathrm{TM}}$ protease inhibitor cocktail (Boehringer, Mannheim; 2 tablets in $100 \mathrm{ml}$ buffer). Extracts were then centrifuged for $15 \mathrm{~min}$ at $15,000 \mathrm{rpm}$ at $4^{\circ} \mathrm{C}$. Enzymes were analysed in the supernatant according to Aebi (1984) for CAT, to Chen and Asada (1989) for APX, to Goldberg and Spooner (1983) for GR and McCord and Fridovich (1969) for SOD as described by Aguilera et al. (2002b) and modified for use of a microtiterplate spectrophotometer (Spectramax, Molecular Devices, Sunnyvale, CA 94089, USA). In order to get replicate measurements, the reaction mixture was scaled up to $2 \mathrm{ml}$ and then dispersed with a multichannel pipette in six slots of the microtiterplate each containing $300 \mu \mathrm{l}$ reaction mixture.

\subsection{Determination of ascorbic acid}

Ascorbic acid was measured according to Foyer et al. (1983), as described by Aguilera et al. (2002b), and also modified in the same way as for the enzymes for use of a microtiterplate spectrophotometer.

\subsection{Protein assay}

Total soluble protein (TSP) content in crude extracts was determined using a commercial Protein Assay (BioRad, Germany), based on the method described by Bradford (1976). Protein content was determined spectrophotometrically at $595 \mathrm{~nm}$ and concentrations were calculated compared to a calibration curve of bovine serum albumin (Sigma, Germany).

\subsection{Determination of phenolic compounds}

The sample of $P$. arctica was lyophylized (135.8 g DW) and extracted with DCM $(3 \times 0.21)$ and then with $\mathrm{MeOH}(3 \times 0.21)$, yielding $2.3 \mathrm{~g} \mathrm{DCM}$ extract and $12.9 \mathrm{~g} \mathrm{MeOH}$ extract. The $\mathrm{MeOH}$ extract was again extracted with acetone, giving $1.0 \mathrm{~g}$ acetone soluble extract. The latter was fractionated on an RP18 vacuum liquid chromatography column (VLC), using $\sim 100 \mathrm{ml}$ solvent per fraction leading to nine fractions. Samples were derivatized with $N$-methyl- $N$-trimethylsilyltriflouracetamid (MSTFA). The analysis was 
carried out on a Perkin-Elmer (Auto system XL) gas chromatograph coupled with a PerkinElmer Turbomass spectrometer using a $30 \mathrm{~m} \times 0.32 \mathrm{~mm}$ N931-6023 Pe-1 (film thickness of $0.25 \mu \mathrm{m})$ capillary column. Conditions: injector $250{ }^{\circ} \mathrm{C}$, split 1:20; temperature program $100-300{ }^{\circ} \mathrm{C}, 6{ }^{\circ} \mathrm{C} / \mathrm{min}$, helium flow $2 \mathrm{ml} / \mathrm{min}$. Mass spectral scan range was $35-650 \mathrm{Da}$.

\subsection{Test systems for antioxidative activities}

\subsubsection{Thiobarbituric acid reactive substances}

The assay was modified after Wallin et al. (1993), and performed as previously described (Abdel-Lateff et al., 2002). Briefly, linolenic acid methyl ester was oxidized in $50 \mathrm{mM}$ phosphate buffer $(\mathrm{pH}=7.2)$, under $\mathrm{FeSO}_{4}$ catalysis. Butylated hydroxytoluene (BHT) in ethanol was added to prevent further oxidation. Thiobarbituric acid reacting substances (TBARS) were determined using trichloroacetic acid and thiobarbituric acid (TBA) at $60{ }^{\circ} \mathrm{C}$ for $30 \mathrm{~min}$. The absorbance was read at $532 \mathrm{~nm}$ less the background absorbance at $600 \mathrm{~nm}$.

2.8.1.1. Calculations. The percentage of inhibition ( $\% \mathrm{I})$ has been calculated from the absorbance readings and is expressed as the inhibition of lipid peroxidation of that sample compared to the not inhibited reaction in the control (Eq. (1)). $A_{\text {blank }}=$ absorbance of the blank $\left(A_{532 \mathrm{~nm}}-A_{600 \mathrm{~nm}}\right), A_{\text {control }}=$ absorbance of the control $\left(A_{532 \mathrm{~nm}}-A_{600 \mathrm{~nm}}\right), A_{\text {sample }}=$ absorbance of the sample $\left(A_{532 \mathrm{~nm}}-A_{600 \mathrm{~nm}}\right), A_{\text {sample blank }}=$ absorbance of the sample blank $\left(A_{532 \mathrm{~nm}}-A_{600 \mathrm{~nm}}\right)$.

$$
\% I=100-\frac{\left(A_{\text {sample }}-A_{\text {sample blank }}\right) \times 100}{A_{\text {control }}-A_{\text {blank }}} .
$$

\subsection{2. $\alpha, \alpha$-Diphenyl- $\beta$-picrylhydrazyl radical (DPPH) assay}

Assays were performed in flat bottom polystyrene 96-well microtiter plates using a modified previously established methodology (Amarowicz et al., 2000; Blois, 1958). To $100 \mu \mathrm{l}$ of each sample $\left(50 \mu \mathrm{g} \mathrm{ml}^{-1}-1 \mathrm{mg} \mathrm{ml}^{-1}\right)$ in EtOH, $25 \mu \mathrm{DPPH}(1 \mathrm{mM})$ in EtOH and $75 \mu \mathrm{EtOH}$ were added. The resultant mixture was briefly shaken and maintained at room temperature, in the dark for $30 \mathrm{~min}$. At the end of this period, the absorbance of the mixture was read at $517 \mathrm{~nm}$, using an SLT Spectral Rainbow microtiter plate reader.

2.8.2.1. Calculations. The percentage of scavenging of DPPH radical from a sample at a given concentration can be calculated from the absorbance readings as shown in Eq. (2).

$$
\% \text { Scavenging }=100-\frac{\left(A_{\text {sample }}-A_{\text {sample blank }}\right) \times 100}{A_{\text {control }}-A_{\text {blank }}} .
$$

\subsection{Statistics}

Mean values and standard deviations of 5-10 replicates per treatment were calculated. The statistical significance of differences in the assay for the detection of the antioxidative potential was tested via a one-way ANOVA followed by a least significant difference test 
(Statistica; Statsoft, Tulsa, USA). Data for the enzyme kinetic were treated by non-linear regression (Statistica; Statsoft) of each concentration compared by an $F$-distribution. For the non-linear regressions polynomic formulae were used.

The following formula was used for the calculation of the $F$-value:

$$
F=[(\mathrm{SQM} 2-\mathrm{SQM} 1) /(\mathrm{FGM} 2-\mathrm{FGM} 1)] /[(\mathrm{SQR} 2 / \mathrm{FGR} 2]
$$

where SQM1 = sum of squares of model 1; SQM2 = sum of squares of model 2; $\mathrm{SQR} 2=$ sum of squares of residuals of model $2 ; \mathrm{FGM} 1=$ degree of freedom model 1 ; FGM2 = degree of freedom model 2; FGR2 = degree of freedom of residuals of model 2.

Model 1 is the sum of two polynomic regressions of the two concentrations to compare. Model 2 consists of the combined data of the two concentrations to compare, building one polynom, it is the big model, because of the higher number of degrees of freedom.

$F$-values higher than table values indicate significant differences. For comparison between the concentrations, each concentration was compared to the control and to the next higher concentration to reduce statistical expense.

\section{Results}

The photosynthetic capacity under $\mathrm{H}_{2} \mathrm{O}_{2}$ stress of the studied species was regarded as indicator for the antioxidative potential. In the group of red algae, $P$. arctica was the most resistant of all investigated species. There were no significant differences in $F_{\mathrm{v}} / F_{\mathrm{m}}$ up to a concentration of $10 \mathrm{mM} \mathrm{H} \mathrm{O}_{2}$. At a concentration of $20 \mathrm{mM} \mathrm{H}_{2} \mathrm{O}_{2}$ the photosynthetic capacity was reduced significantly $(p<0.0001)$ by $20 \%$ (Fig. 1$)$. In contrast, incubation in 5 $\mathrm{mM} \mathrm{H} \mathrm{H}_{2} \mathrm{O}_{2}$ resulted in a significant reduction of the maximum quantum yield of $55 \%$ in

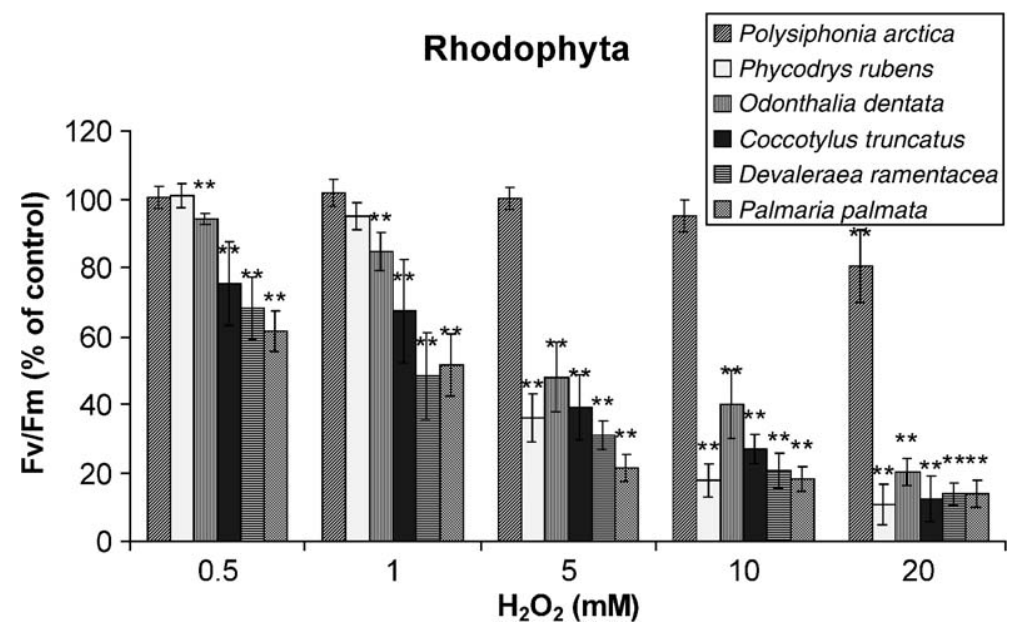

Fig. 1. The effect of increasing $\mathrm{H}_{2} \mathrm{O}_{2}$ concentrations on the maximum quantum yield of six red macroalgae from Kongsfjorden, Spitsbergen, mean values \pm S.D., $n=10 . F_{\mathrm{v}} / F_{\mathrm{m}}$ values of the control were between 0.54 and 0.57 for all the red algae. ${ }^{*}, *$ : Significant differences to the control value at $p<0.05$ and $p<0.01$, respectively. 


\section{Chlorophyta}

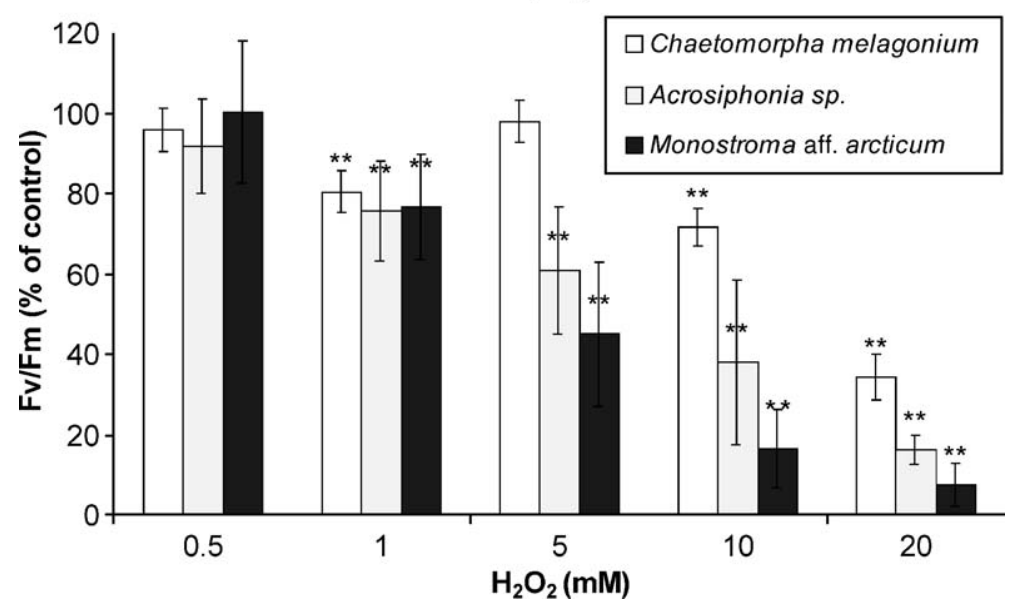

Fig. 2. The effect of increasing $\mathrm{H}_{2} \mathrm{O}_{2}$ concentrations on the maximum quantum yield of three green macroalgae from Kongsfjorden, Spitsbergen, mean values \pm S.D., $n=10 . F_{\mathrm{v}} / F_{\mathrm{m}}$ values of the control were 0.61 for $C$. melagonium, 0.71 for Acrosiphonia sp. and 0.49 for M. arcticum. ***: Significant differences to the control value at $p<0.05$ and $p<0.01$, respectively.

Phycodrys rubens $(p<0.0001)$ and $64 \%$ in Odonthalia dentata $(p<0.0001$, Fig. 1). Coccotylus truncatus, Devaleraea ramentacea and Palmaria palmata were most sensitive to $\mathrm{H}_{2} \mathrm{O}_{2}$. After incubation in $1 \mathrm{mM} \mathrm{H}_{2} \mathrm{O}_{2} F_{\mathrm{v}} / F_{\mathrm{m}}$, values decreased to $73 \%(p<0.0001), 47 \%$ $(p<0.0001)$ and $50 \%(p<0.0001)$ in the three species, respectively (Fig. 1). Within the

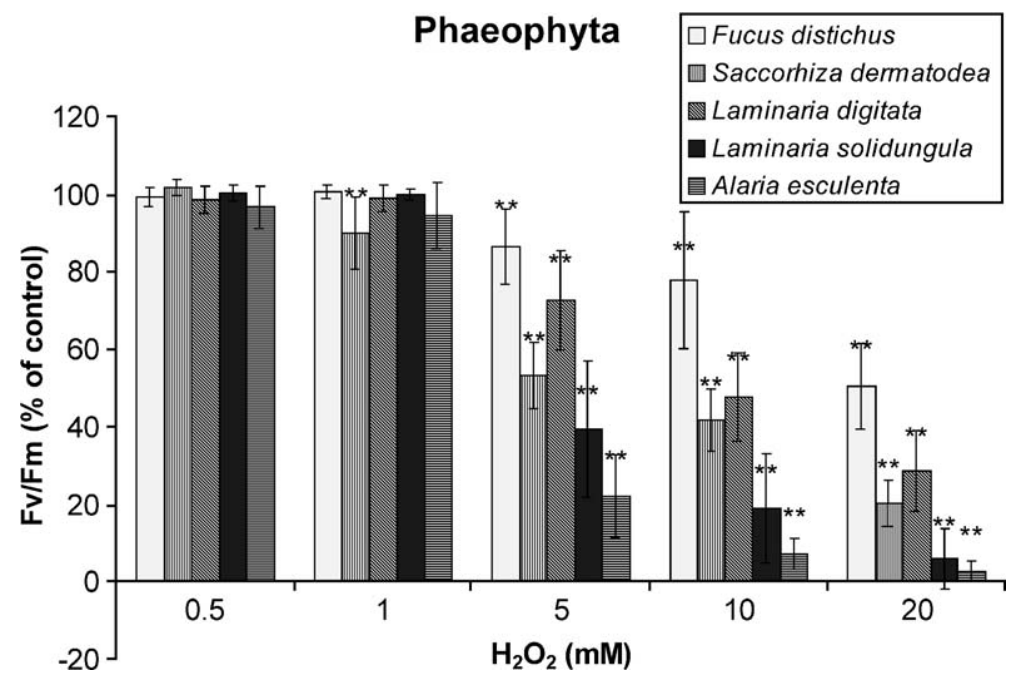

Fig. 3. The effect of increasing $\mathrm{H}_{2} \mathrm{O}_{2}$ concentrations on the maximum quantum yield of five brown macroalgae from Kongsfjorden, Spitsbergen, mean values \pm S.D., $n=10 . F_{\mathrm{v}} / F_{\mathrm{m}}$ values of the control were between 0.70 and 0.77 for all brown algae. ${ }^{*} * *$ : Significant differences to the control value at $p<0.05$ and $p<0.01$, respectively. 


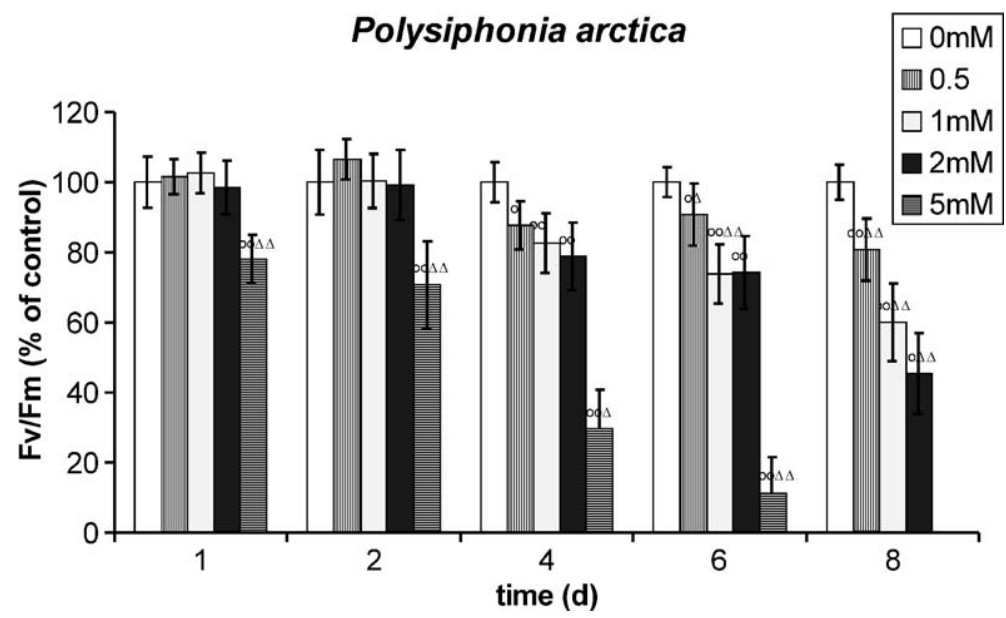

Fig. 4. $F_{\mathrm{v}} / F_{\mathrm{m}}$ mean values \pm S.D. (\% of control) of $P$. arctica after incubation in a series of ascending hydrogen peroxide concentrations in relation to incubation time, $n=10 . F_{\mathrm{v}} / F_{\mathrm{m}}$ values of the daily controls were between 0.54 (day 8) and 0.61 (day1). $\bigcirc, 0 \bigcirc$ : Significant differences to the control at $p<0.05$ and $p<0.01$, respectively. $\triangle, \triangle \triangle$ : Significant differences to the preceding concentration at $p<0.05$ and $p<0.01$, respectively.

green algae, $C$. melagonium showed the highest resistance against $\mathrm{H}_{2} \mathrm{O}_{2}$ (Fig. 2). $F_{\mathrm{v}} / F_{\mathrm{m}}$ decreased significantly $(p<0.0001)$ to $73 \%$ of the control after exposure to $10 \mathrm{mM} \mathrm{H}_{2} \mathrm{O}_{2}$ whereas Acrosiphonia sp. and Monostroma aff. arcticum were more susceptible to concentrations $\geq 5 \mathrm{mM}$. All brown algae tolerated up to $1 \mathrm{mM} \mathrm{H}_{2} \mathrm{O}_{2}$. In $F$. distichus the $F_{\mathrm{v}} / F_{\mathrm{m}}$ value was significantly reduced $(p<0.0001)$ but still above $50 \%$ in $20 \mathrm{mM} \mathrm{H}_{2} \mathrm{O}_{2}$ (Fig. 3). Laminaria digitata and Sacchorhiza dermatodea showed a 50\% $(p<0.0001)$ reduction in quantum yield at $10 \mathrm{mM} \mathrm{H} \mathrm{H}_{2} \mathrm{O}_{2}$. In the most sensitive phaeophyte species, Laminaria solidungula and Alaria esculenta, incubation in $5 \mathrm{mM} \mathrm{H}_{2} \mathrm{O}_{2}$ resulted in a significant decline of $F_{\mathrm{v}} / F_{\mathrm{m}}$ by $60 \%(p<0.0001)$ and $80 \%(p<0.0001)$, respectively (Fig. 3$)$.

Table 2

Statistical evaluation of APX and CAT activities $\left(\mathrm{U} \mathrm{g} \mathrm{DW}^{-1}\right)$ in $P$. arctica in relation to time and $\mathrm{H}_{2} \mathrm{O}_{2}$ concentration (see Figs. 5 and 6) after non-linear regression resulting in $F$ and p values

\begin{tabular}{|c|c|c|c|c|}
\hline \multirow[t]{2}{*}{ Comparison } & \multicolumn{2}{|l|}{$\mathrm{APX}$} & \multicolumn{2}{|l|}{ CAT } \\
\hline & $F$ & $p$ & $F$ & $p$ \\
\hline $0 / 0.5$ & 14.27 & $0.024 *$ & 21.40 & $0.013^{*}$ \\
\hline $0 / 1$ & 100.10 & $0.001 * *$ & 60.34 & $0.003 * *$ \\
\hline $0 / 2$ & 75.33 & $0.002 * *$ & 33.70 & $0.007 * *$ \\
\hline $0 / 5$ & 27.44 & $0.009 * *$ & 53.53 & $0.003 * *$ \\
\hline $0.5 / 1$ & 81.27 & $0.002 * *$ & 30.74 & $0.008 * *$ \\
\hline $1 / 2$ & 7.64 & 0.058 & 22.55 & $0.012 *$ \\
\hline $2 / 5$ & 18.23 & $0.017 *$ & 19.86 & $0.015^{*}$ \\
\hline
\end{tabular}

Each concentration was compared to the control and the next higher concentration. For detailed description of the test, see Material and methods.

* Indicating statistical significance at $P<0.05$.

** At $P<0.01$ 


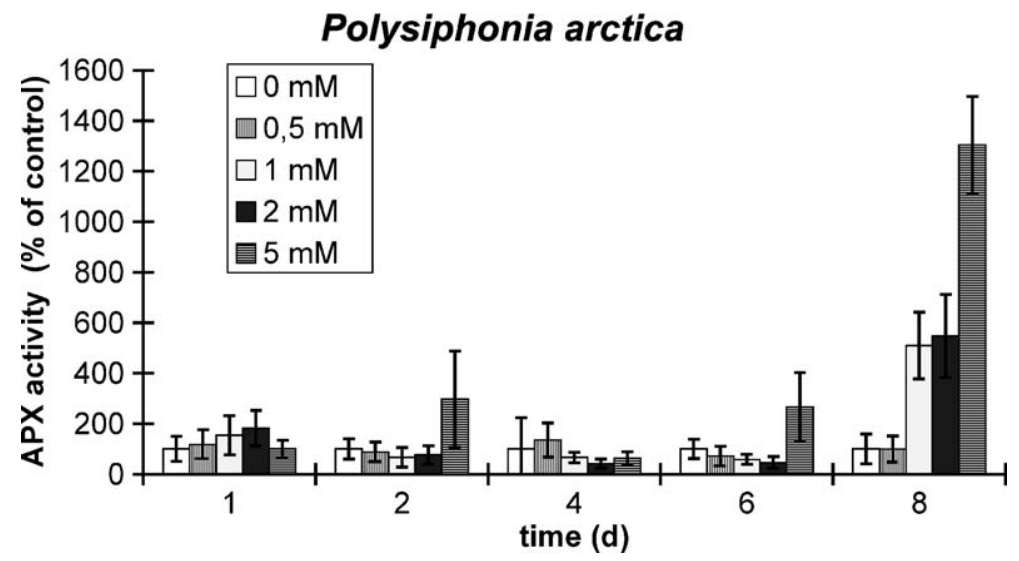

Fig. 5. Kinetic of APX activity under $\mathrm{H}_{2} \mathrm{O}_{2}$ stress in $P$. arctica ( $\%$ of control, related to $\mathrm{U}$ mg TSP $\left.{ }^{-1}\right)$, mean values \pm S.D., $n=5$.

Maximum quantum yield of $P$. arctica was gradually reduced under $\mathrm{H}_{2} \mathrm{O}_{2}$ stress in dependency of exposure time and $\mathrm{H}_{2} \mathrm{O}_{2}$ concentration. In the first $24 \mathrm{~h}$ of exposure, $F_{\mathrm{v}} / F_{\mathrm{m}}$ remained unchanged up to $2 \mathrm{mM} \mathrm{H}_{2} \mathrm{O}_{2}$ treatment (Fig. 4). Even a slight increase in $F_{\mathrm{v}} / F_{\mathrm{m}}$ could be recorded at 0.5 and $1 \mathrm{mM}$ in the first $24 \mathrm{~h}$ of exposure. At $5 \mathrm{mM} \mathrm{H}_{2} \mathrm{O}_{2}, F_{\mathrm{v}} / F_{\mathrm{m}}$ was significantly reduced to $78 \%$ of the control $(p<0.0001$, Fig. 4$)$. The same pattern was observed after 2 days of exposure. After 4 days of exposure, a drastic decrease in $F_{\mathrm{v}} / F_{\mathrm{m}}$ was recorded for the $5 \mathrm{mM}$ treatment differing significantly to the control as well as to all other treatments $(p<0.0001$, Fig. 4). The treatments of $0.5-2 \mathrm{mM}$ showed also a gradual reduction of $F_{\mathrm{v}} / F_{\mathrm{m}}$ values along the concentration gradient, each differing significantly to the control with $p<0.01$, as well as the $2-\mathrm{mM}$ treatment to the $0.5-\mathrm{mM}$ treatment with $p<0.02$. After 6 days of exposure, all treatments showed significantly reduced $F_{\mathrm{v}} / F_{\mathrm{m}}$ values

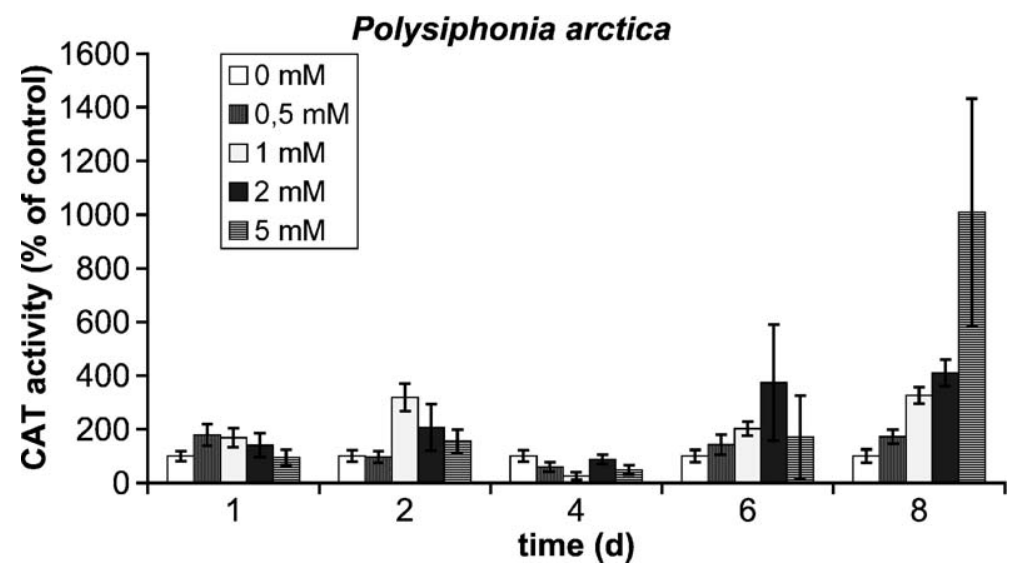

Fig. 6. Kinetic of CAT activity under $\mathrm{H}_{2} \mathrm{O}_{2}$ stress in $P$. arctica (\% of control, related to $\mathrm{U}$ mg $\mathrm{TSP}^{-1}$ ), mean values \pm S.D., $n=5$. 
( $p<0.0$ for $1-5 \mathrm{mM}$ and $p<0.015$ for $0.5 \mathrm{mM}$ ). Under the highest $\mathrm{H}_{2} \mathrm{O}_{2}$ concentration, $F_{\mathrm{v}} / F_{\mathrm{m}}$ decreased to $11 \%$ of the control $(p<0.0001)$ and the thalli of $P$. arctica started to bleach. In the 1- and 2-mM treatments the reduction went on, resulting in $F_{\mathrm{v}} / F_{\mathrm{m}}$ values of $74 \%$ of the control, differing significantly to the control $(p<0.0001)$ and to $0.5 \mathrm{mM}$ $\left(p<0.0001\right.$, Fig. 4). After 8 days of exposure, the gradual reduction of $F_{\mathrm{v}} / F_{\mathrm{m}}$ was most obvious. Exposure to $0.5 \mathrm{mM} \mathrm{H}_{2} \mathrm{O}_{2}$ resulted in a decrease of $F_{\mathrm{v}} / F_{\mathrm{m}}$ to $80 \%$ of the control $(p<0.0001)$, in the $1-\mathrm{mM}$ treatment a significant reduction to $60 \%$ of the control was recorded $(p<0.0001)$ and $45 \%$ under $2 \mathrm{mM} \mathrm{H}_{2} \mathrm{O}_{2}(p<0.0001$, Fig. 4$)$. The bleaching process now also affected thalli exposed to $2 \mathrm{mM} \mathrm{H}_{2} \mathrm{O}_{2}$. Concomitantly the alga exhibited a much softer consistency. In the 5-mM treatment, no photosynthetic activity was found (Fig. 4).

APX activity in $P$. arctica showed an induction with increasing $\mathrm{H}_{2} \mathrm{O}_{2}$ stress. After 1 day of exposure, the gradual increase of APX activity is obvious up to concentrations of $2 \mathrm{mM}$
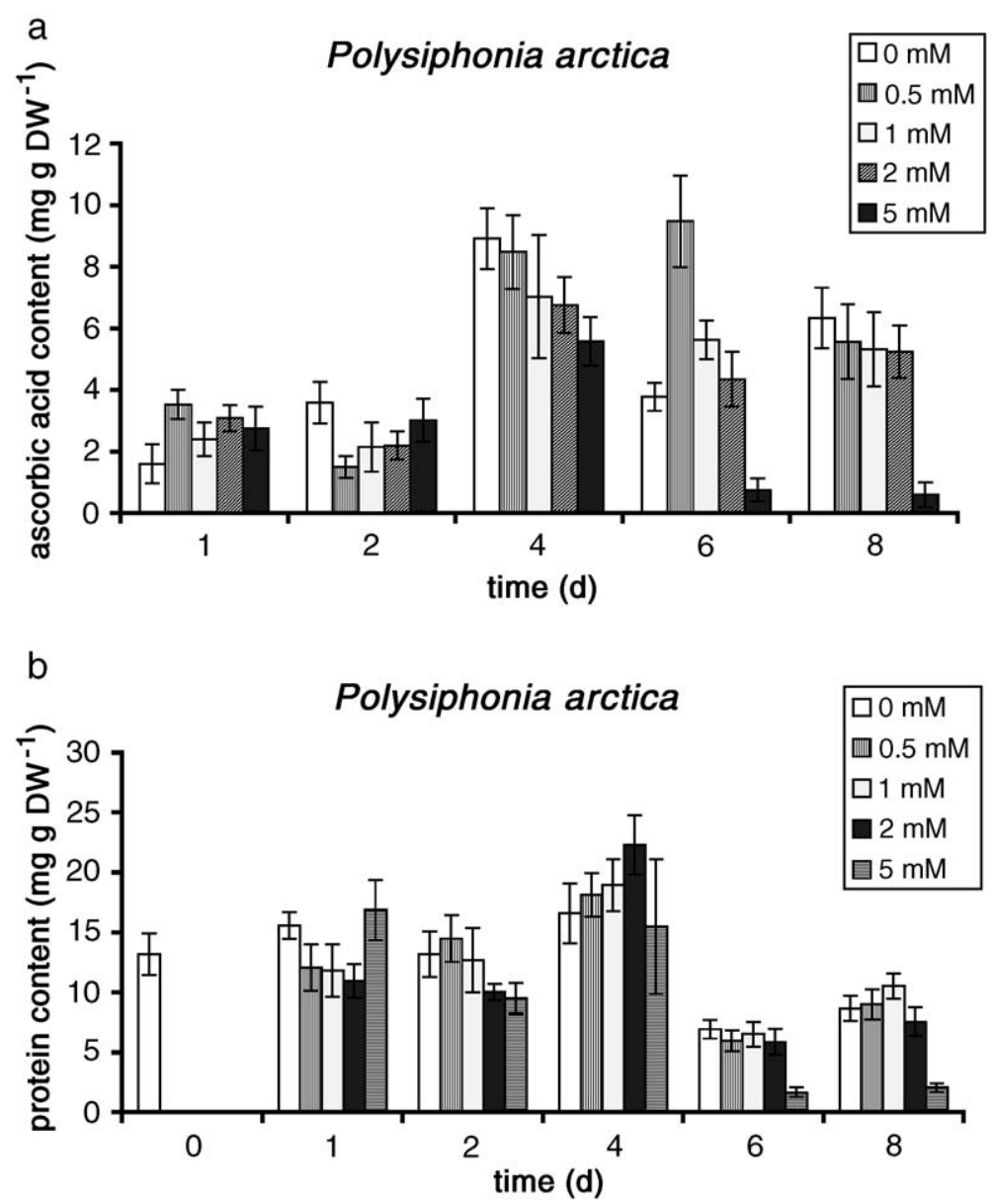

Fig. 7. (a) Ascorbic acid content $\left(\mathrm{mg} \mathrm{g} \mathrm{DW}^{-1}\right)$ and (b) protein content $\left(\mathrm{mg} \mathrm{g} \mathrm{DW}^{-1}\right)$ in P. arctica after incubation in a series of ascending hydrogen peroxide concentrations in relation to incubation time, $n=5$. 
$\mathrm{H}_{2} \mathrm{O}_{2}$; the 5-mM treatment showed a delay, which was cached up with ongoing of the exposure time. Enzyme activities differed significantly to the control, as well as the treatments from each other except the 1- and 2-mM treatments, $p$-values are given in Table 2. Enzyme activity was up to 13 -fold higher $(p<0.009)$ in $5 \mathrm{mM} \mathrm{H}_{2} \mathrm{O}_{2}$ in comparison to the control with $2.9 \mathrm{U} \mathrm{mg} \mathrm{TSP}^{-1}$ (Fig. 5, Table 2). Maximum APX activity was recorded in $1-5 \mathrm{mM} \mathrm{H}_{2} \mathrm{O}_{2}$ on day 8 of the experiment (Fig. 5).

CAT activity in $P$. arctica was induced by $\mathrm{H}_{2} \mathrm{O}_{2}$ within the first $24 \mathrm{~h}$ of the experiment. After exposure to $0.5 \mathrm{mM} \mathrm{H}_{2} \mathrm{O}_{2}$, the CAT activity rose to $180 \%$ (Fig. 6) corresponding to 7 $\mathrm{U} \mathrm{mg} \mathrm{TSP}{ }^{-1}$. Exposure to 1 and $2 \mathrm{mM} \mathrm{H}_{2} \mathrm{O}_{2}$ lead to activities of $141 \%$ and $168 \%$ of the control, respectively (Fig. 6). After 4 days of exposure, the lowest CAT activities were
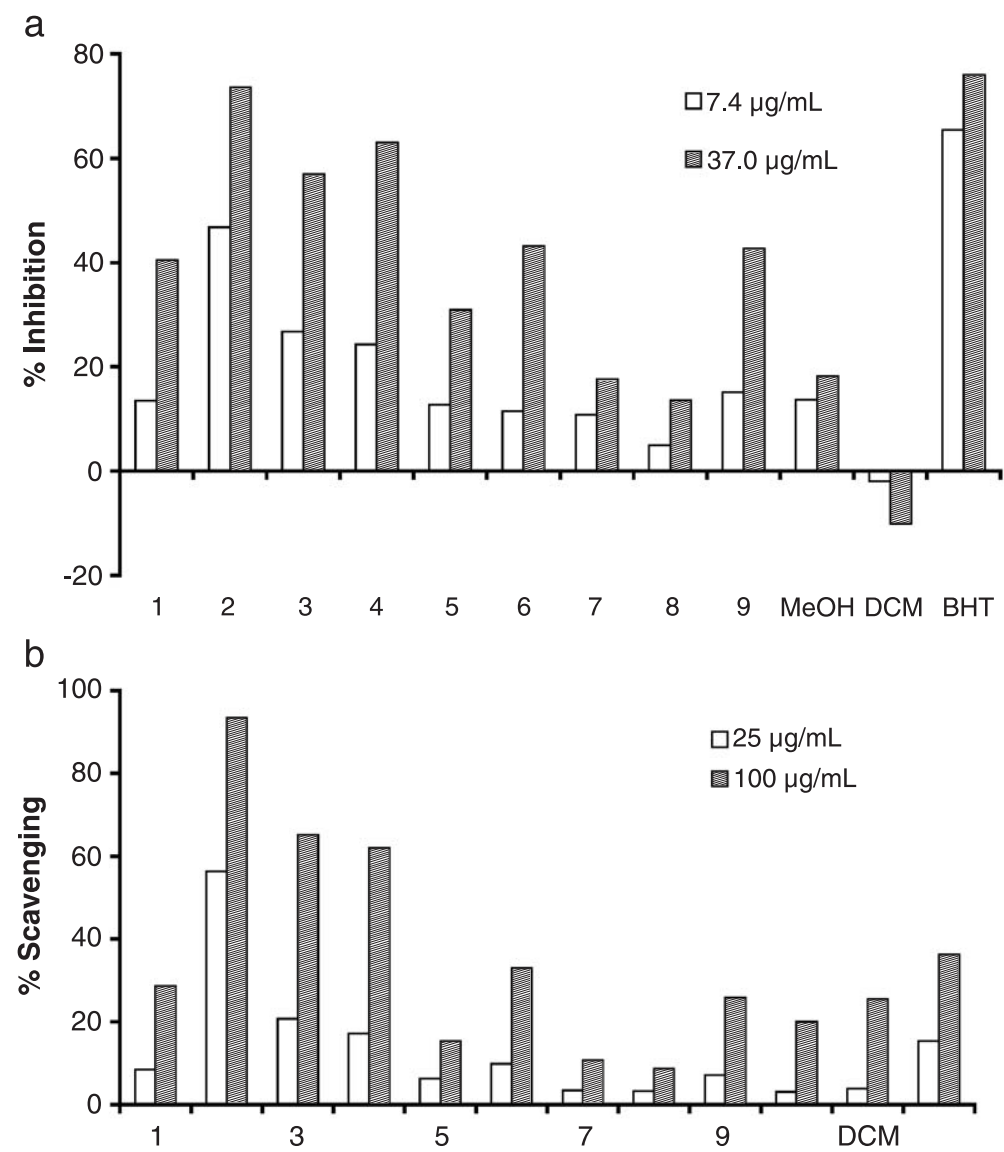

Fig. 8. (a) Inhibition of linolenic acid methyl ester oxidation by $P$. arctica extracts and acetone soluble fractions in the TBARS assay, positive control: butylated hydroxytoluene $(\mathrm{BHT}) . \%$ Inhibition $=100-\left(A_{\text {sample }}-A_{\text {sample }}\right.$ blank $) \times 100 /\left(A_{\text {control }}-A_{\text {blank }}\right)$. (b) Scavenging activity of $P$. arctica extracts and acetone soluble fractions in the $\mathrm{DPPH}$ assay, positive control: butylated hydroxytoluene (BHT). \%Scavenging $=100-\left(A_{\text {sample }}-A_{\text {sample }}\right.$ blank $) \times 100 /\left(A_{\text {control }}-A_{\text {blank }}\right)$. 
measured with $25-86 \%$ of the control. From day 6 onwards, CAT activity increased with increasing $\mathrm{H}_{2} \mathrm{O}_{2}$ concentration to a 10 -fold higher value. Maximum CAT activity was found after 8 days in $5 \mathrm{mM} \mathrm{H}_{2} \mathrm{O}_{2}$ with $34 \mathrm{U} \mathrm{mg} \mathrm{TSP}^{-1}$. CAT activities differed significantly to the control, as well as the treatments from each other, regarding the different treatments each as one unit described by a polynomic curve. $p$-Values are given in Table 2.

In $P$. arctica, the ascorbic acid content increased during the first $24 \mathrm{~h}$ of exposure in all $\mathrm{H}_{2} \mathrm{O}_{2}$ concentrations. On day 2, ascorbic acid content decreased and on day 6 it increased strongly when exposed to $0.5 \mathrm{mM} \mathrm{H}_{2} \mathrm{O}_{2}$. Under high $\mathrm{H}_{2} \mathrm{O}_{2}$ stress $(5 \mathrm{mM})$, the ascorbic acid content decreased from $2.75 \mathrm{mg} \mathrm{g} \mathrm{DW}^{-1}$ at the beginning to $0.59 \mathrm{mg} \mathrm{g} \mathrm{DW}^{-1}$ after 8 days of treatment (Fig. 7a).

The protein content of $P$. arctica varied between 11 and $18 \mathrm{mg} \mathrm{g} \mathrm{DW}^{-1}$ within the first 4 days of exposure; in the following 4 days protein content fell below $10 \mathrm{mg} \mathrm{g} \mathrm{DW} \mathrm{DW}^{-1}$ (Fig. 7b). At the end of the experiment, the protein content of thalli exposed to 2 and $5 \mathrm{~m}$ $\mathrm{H}_{2} \mathrm{O}_{2}$ decreased below $2 \mathrm{mg} \mathrm{g} \mathrm{DW}^{-1}$ (Fig. 7b).

\subsection{Antioxidative potential as determined by TBARS and DPPH assay}

In order to determine compounds that may influence the resistance of $P$. arctica to oxidative stress the alga was extracted with lipophilic and hydrophilic solvents. Subsequently the antioxidative activity of extracts and fractions, obtained after chromatographic separation, was assessed. $P$. arctica showed both prooxidative activity in the DCM extract and antioxidative activity in the $\mathrm{MeOH}$ extract as determined by the TBARS assay. Fractions of the $\mathrm{MeOH}$ extract from $P$. arctica were again tested in the TBARS assay at concentrations of 7 and $37 \mu \mathrm{g} \mathrm{ml}{ }^{-1}$. Fraction 2 showed the strongest inhibitory effect on linolenic acid methyl ester oxidation at both concentrations (Fig. 8a). At $37 \mu \mathrm{g} \mathrm{ml} \mathrm{m}^{-1}$, the inhibition of fraction 2 was in the same range as that of BHT, whereas at $7 \mu \mathrm{g} \mathrm{ml}^{-1}$ inhibition was clearly less than that of the positive control. The $\mathrm{MeOH}$ extract and the fractions of the $\mathrm{MeOH}$ extract from $P$. arctica were also tested in the DPPH assay at concentrations of 25, 50,100,500 $\mu \mathrm{g} \mathrm{ml} \mathrm{m}^{-1}$. Results from concentrations at 25 and $100 \mu \mathrm{g} \mathrm{ml}^{-1}$ are given in Fig. 8b. In the DPPH assay, fraction

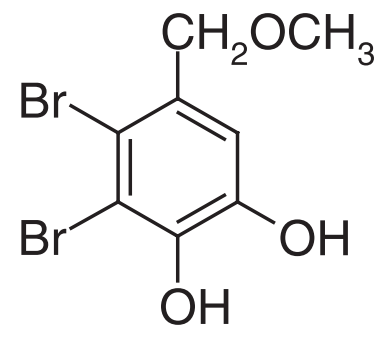

1

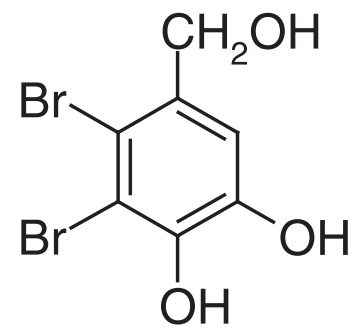

2

Fig. 9. Chemical structure of the bromophenolic compounds in P. arctica. 
2 was also the most active one. The radical scavenging activity was much stronger than that of BHT at both concentrations.

All fractions tested for their antioxidative activity were analysed by GC-MS for their bromophenol content. Only in fraction 2 could bromophenols be identified. A chromatogram of fraction 2 contained as major metabolites compound $\mathbf{1}$ identified as the TMS derivative of 2,3-dibromo-4,5-dihydroxybenzyl methyl ether, and $\mathbf{2}$ the TMS derivative of 2,3-dibromo-4,5-dihydroxybenzyl alcohol. Formulas are given in Fig. 9.

\section{Discussion}

The present study gives an insight into the antioxidative properties of Arctic marine macroalgae under artificial $\mathrm{H}_{2} \mathrm{O}_{2}$ stress. Using PS II fluorescence as indicator we identified species with a high antioxidative potential in short-term stress experiments. The plants with high photosynthetic activity under oxidative stress, were $C$. melagonium as representative of the green algae, F. distichus belonging to the brown algae and $P$. arctica within the red algae. Since the latter species exhibited the highest tolerance against $\mathrm{H}_{2} \mathrm{O}_{2}$ among all the algae tested, long-term exposure of $P$. arctica to $\mathrm{H}_{2} \mathrm{O}_{2}$ was investigated as well. The underlying mechanisms of protection and defense against oxidative stress were studied in detail.

The maximum quantum yield of photosynthesis is a common parameter in plant ecophysiology and stress research and expressed as the ratio of variable to maximum chlorophyll fluorescence $\left(F_{\mathrm{v}} / F_{\mathrm{m}}\right)$. The method of PAM fluorometry offers the advantage that the plant is not stressed or damaged by the technique itself (Bilger et al., 1995) and it allows fast assessment of photosynthetic activity. As oxidative stress directly intervenes in the photosynthetic process we found that this method can also be used to determine the relative antioxidative properties of macroalgae. Collen and Pedersen (1996) already tested the effects of $\mathrm{H}_{2} \mathrm{O}_{2}$ on variable fluorescence of the green alga Ulva rigida. In this species the variable fluorescence was not influenced by exposure to concentrations lower than 1 $\mathrm{mM}$, however was totally inhibited at $100 \mathrm{mM} \mathrm{H}_{2} \mathrm{O}_{2}$. This is in agreement with our data, at least for short-term treatments. Therefore, PAM fluorometry is a suitable technique to rapidly screen for the antioxidative potential in comparative studies in macroalgae. For longer exposure times, as performed for $P$. arctica in the present study, $F_{\mathrm{v}} / F_{\mathrm{m}}$ is also affected at concentrations lower than $1 \mathrm{mM}$, indicating that concentration as well as exposure time are responsible for the observed toxic effects.

The species with the highest antioxidative potential, $C$. melagonium, $F$. distichus and $P$. arctica, are also described by Aguilera et al. (2002b) as macroalgae with high antioxidative properties. C. melagonium possesses high enzyme activities of SOD and CAT, which are typical for green macroalgae and explaining the high capability of resistance of these algae against $\mathrm{H}_{2} \mathrm{O}_{2}$ stress (Aguilera et al., 2002b). The high antioxidative properties of $F$. distichus can be explained by enzyme and non-enzymatic mechanisms such as SOD activity of $151 \mathrm{U} \mathrm{mg} \mathrm{TSP}^{-1}, 3.6 \mathrm{U} \mathrm{mg} \mathrm{TSP}^{-1} \mathrm{CAT}$ and $0.29 \mathrm{mg} \mathrm{g} \mathrm{FW}^{-1}$ of ascorbic acid (Aguilera, 2002b). As representative of brown seaweeds, F. distichus also possesses phenolic compounds which can act as antioxidants. $P$. arctica showed high APX activity with $0.43-1.14 \mathrm{U} \mathrm{mg} \mathrm{TSP}^{-1}$, which was up to 50-fold higher for $\mathrm{H}_{2} \mathrm{O}_{2}$-treated thalli, in comparison to data on untreated thalli presented by Aguilera et al. (2002b) for this species. 
The big discrepancy between these data could have resulted from strong seasonal differences in enzyme activities as shown in Aguilera et al. (2002a) for SOD, CAT and GR for several macroalgal species from the Arctic. The activities of antioxidant enzymes such as APX, catalases and SODs are up-regulated in response to several abiotic stresses such as drought (Smirnoff and Colombe, 1988), low temperatures (Schöner and Krause, 1990), high light intensities (Camak and Marschner, 1992), ozone, $\mathrm{SO}_{2}$, UV-B (Willekens et al., 1994) and salinity (Lopez et al., 1996).

In this study, this general statement is also true for $P$. arctica which had enhanced APX and CAT activities with increasing $\mathrm{H}_{2} \mathrm{O}_{2}$ concentrations on a basis of TSP but not for dry weight normalized data. Also GR activity was enhanced with increasing $\mathrm{H}_{2} \mathrm{O}_{2}$ concentrations from 0.02 to $0.05 \mathrm{U} \mathrm{mg} \mathrm{TSP}^{-1}$ (data not shown) as well as SOD maintained high activities, varying between 48 and $97 \mathrm{U} \mathrm{mg} \mathrm{TSP}^{-1}$, throughout the experiment (data not shown).

But there are also several examples showing decrease of antioxidative enzymes under stress. Schriek (2000) for example measured decreased GR activities in the diatoms Entemoneis kufferathii and Chaetoceros sp. with increasing temperature and light intensities. Aguilera et al. (2002b) showed decreased SOD activities in P. palmata and decreased GR activities in Monostroma aff. arcticum under UV radiation. In the case of $\mathrm{UV}$, this could be a direct radiation damage to the enzyme as discussed for catalase in higher plants (Foyer and Mullineaux, 1994), because many proteins absorb short wavelengths of UVB and thereby may break disulfide bridges that are essential for native structure and function. High levels of $\mathrm{H}_{2} \mathrm{O}_{2}$ ( $3 \mathrm{mM}$ and above) caused oxidative stress in $U$. rigida (Collen and Pedersen, 1996) and finally led to cell death due to enzyme damage. This seems also the case in our study for $P$. arctica treated with 2 and $5 \mathrm{mM} \mathrm{H}_{2} \mathrm{O}_{2}$. The bleaching of the algal thalli after 6 days of incubation fortify this thesis.

The content of TSP in $P$. arctica was negatively affected by $\mathrm{H}_{2} \mathrm{O}_{2}$ stress, particularly after 8 days of treatment. The bleaching of the algal thalli after 4 days explained the drastic decline in protein content most probably due to the degradation of phycobiliproteins. At the same time, photosynthetic efficiency was reduced drastically under high $\mathrm{H}_{2} \mathrm{O}_{2}$ stress as a result of fewer pigments working for photosynthesis. If the protein content is considerably lower than the control value, a much higher protein-based enzyme activity would result from the calculation. Negatively effected protein content after $\mathrm{H}_{2} \mathrm{O}_{2}$ stress was also described by Pastori and Trippi (1993), whereas the enzyme activities of APX and SOD were increasedwhich support the data presented here for APX and CAT. The interpretation of the enzyme activity data should be made carefully. Ascorbic acid content in P. arctica was reduced under high $\mathrm{H}_{2} \mathrm{O}_{2}$ concentrations and after longer exposure times to $\mathrm{H}_{2} \mathrm{O}_{2}$ only. This decline of ascorbic acid correlates well with an obvious stimulation in APX and CAT activity. This could be explained by ascorbic acid acting as primary protection mechanisms against $\mathrm{H}_{2} \mathrm{O}_{2}$ and the activity of antioxidative enzymes as secondary protection system. From an energetic standpoint the synthesis of ascorbic acid is not as costly for the plant as the de novo synthesis of protective enzymes. In spite of strongly reduced photosynthesis after 8 days of exposure to $\mathrm{H}_{2} \mathrm{O}_{2}$ concentrations $<2 \mathrm{mM}$, other metabolic reactions such as the antioxidative enzymes could be recorded, indicating that the enhancement of antioxidative enzymes was not sufficient to sustain photosynthesis.

In comparison to other marine macroalgae such as Fucus species (Collen and Davison, 1999a), APX activity in P. arctica was 1- to 3-fold lower, assuming a DW/FW ratio of 1:10. 
Despite the fact that it showed rather moderate antioxidative enzyme activities and ascorbic acid concentrations, $P$. arctica was extremely resistant against $\mathrm{H}_{2} \mathrm{O}_{2}$ in our assay, indicating the presence of other antioxidative compounds and mechanisms, respectively.

Further investigations of extracts from $P$. arctica evince the existence of bromophenolic compounds with antioxidative properties. The bromophenolic compounds were identified by GC-MS and their antioxidative abilities tested by TBARS and DPPH assays. The identified compounds resemble bromophenolic substances earlier described for several Polysiphonia species (Glombitza et al., 1974; Kurata and Amiya, 1980). The correlation of bromophenol content with high antioxidative activity in fraction 2 indicates that $P$. arctica contains bromophenols as low molecular weight antioxidants. Since fractions 3 and 4 also show notable antioxidant activity in the TBARS assay, other low molecular weight antioxidants could also be present in this alga. The extraction of the algae was done with $\mathrm{MeOH}$, therefore, the 2,3-dibromo-4,5-dihydroxybenzyl methyl ether (1) could be an isolation artefact of (2). Glombitza et al. (1974) mainly found dibromophenols among the investigated Polysiphonia species. Only Polysiphonia urceolata contained monobromophenols as main bromophenols. In the GC-MS analysis of $P$. arctica, no monobromophenols were found.

In general, macroalgae from eulittoral and upper sublittoral have to cope with changing environmental conditions such as light (photosynthetic active radiation and ultraviolet radiation), temperature, salinity and desiccation. For this reason, it is obvious that species inhabiting the eulittoral and upper sublittoral exhibit higher enzyme activities and antioxidant concentrations as species inhabiting deeper waters. This relation between antioxidant capabilities and depth distribution has been suggested by Aguilera et al. (2002a,b) and accounts for the high resistibility to oxidative $\mathrm{H}_{2} \mathrm{O}_{2}$ stress of the Chaetomorpha species and $F$. distichus living in the eulitoral and upper sublitoral. Collen and Davison (1999b) also explain the increase of activities of reactive oxygen scavenging enzymes with increased environmental stress in the higher intertidal for Mastocarpus stellatus. High tolerance to various stresses of species from the uppermost sublittoral zone is also documented by Davison and Pearson (1996). For the Chaetomorpha species and F. distichus, this relation between tidal height and antioxidative properties is a possible explanation but not for $P$. arctica as a deep waters species living from 12 to $30 \mathrm{~m}$ where light stress (UV and high light) and light-induced oxidative stress do not occur. As $P$. arctica is occupied by a dense population of epiphytic diatoms which produce photosynthetic oxygen, this could be a possible explanation why a deepwater species possesses such a high antioxidative potential.

The different plant species show different strategies against oxidative stress. The responses in this study are time- and dose-dependent. As Collen and Davison (1999a) pointed out, the key element in reactive oxygen metabolism might be the balance between production and protection in individual compartments, such as chloroplasts rather than protection integrated over the entire cell. Our study supports this theory.

\section{Acknowledgements}

The authors would like to thank the diving team (Heike Lippert, Stefan Kremb, Tanja Michler and Stefanie Bröhl) for support by sampling, as well as the material from 
Koldewey station and the Ny Alesund International research monitoring facility. This project was financially supported by the German Ministry of Education and Research (BMBF; Project: "MONA"; 03FO229A). [SS]

\section{References}

Abdel-Lateff, A., König, G.M., Fisch, K.M., Höller, U., Jones, P.G., Wright, A.D., 2002. New antioxidant hydroquinone derivatives from the algicolous marine fungus Acremonium sp. J. Nat. Prod. 65 (11), $1605-1611$.

Aebi, H., 1984. Catalase in vitro. Method Enzymol. 105, 121-130.

Aguilera, J., Bischof, K., Karsten, U., Hanelt, D., Wiencke, C., 2002a. Seasonal variation in ecophysiological patterns in macroalgae from an Arctic fjord: II. Pigment accumulation and biochemical defence systems against high light stress. Mar. Biol. 140, 1087-1095.

Aguilera, J., Dummermuth, A.L.K.U., Schriek, R., Wiencke, C., 2002b. Enzymatic defences against photooxidative stress induced by ultraviolet radiation in Arctic marine macroalgae. Polar Biol. 25, 432-441.

Allen, J.F., 1977. Superoxide and photosynthetic reduction of oxygen. In: Michelson, A.M., et al. (Ed.), Superoxide and Superoxide Dismutases. Academic Press, New York, pp. 417-436.

Amarowicz, R., Naczk, M., Shahidi, F., 2000. Antioxidant activity of various fractions of non-tannin phenolics of Canula hulls. J. Agric. Food Chem. 48, 2755-2759.

Apostol, I., Heinstein, P.F., Low, P.S., 1989. Rapid stimulation of an oxidative burst during elicitation of cultured plant cells. Plant, 109-116.

Asada, K., 1994a. Mechanisms for scavenging reactive molecules generated in chloroplasts under light stress. In: Post, A., Baker, N.R., Bowyer, J.R. (Eds.), Photoinhibition of Photosynthesis: from Molecular Mechanisms to the Field. BIOS Scientific Publishers, Oxford, pp. 128-140.

Asada, K., 1994b. Production and action of active oxygen species in photosynthetic tissues. In: Foyer, C.H., Mullineaux, P.M. (Eds.), Causes of Photooxidative Stress and Amelioration of Defence Systems in Plants. CRC Press, Boca Raton, pp. 77-104.

Asada, K., Takahashi, M., 1987. Production and scavenging of active oxygen in photosynthesis. In: Kyle, D.J., Osmond, C.B., Arntzen, C.J. (Eds.), Photoinhibition. Elsevier, Amsterdam, pp. 227-287.

Asada, K., Yoshikawa, K., Takahashi, M., Maeda, Y., Enmanji, K., 1975. Superoxide dismutase from a bluegreen alga Plectonema boryanum. J. Biol. Chem. 250, 2801-2807.

Badger, M.R., Andrews, T.J., Cavini, D.T., Lorimer, G.M., 1980. Interactions of hydrogen peroxide with ribulose bisphosphate carboxylase oxygenase. J. Biol. Chem. 255, 7870-7875.

Bilger, W., Schreiber, U., Bock, M., 1995. Determination of the quantum efficiency of photosystem II and of nonphotochemical quenching of chlorophyll fluorescence in the field. Oecologia 102, 425-432.

Bischof, K., Hanelt, D., Wiencke, C., 2000. Effects of ultraviolet radiation on photosynthesis and related enzyme reactions of marine macroalgae. Planta 211, 555-562.

Blois, M.S., 1958. Antioxidant determinations by the use of a stable free radical. Nature 181, 1199-1200.

Bradford, M., 1976. A rapid and sensitive method for the quantification of micrograms quantities of protein utilizing the principle of protein-dye binding. Anal. Biochem. 72, 248-254.

Camak, I., Marschner, H., 1992. Magnesium deficiency and high light intensity enhance activities of superoxide dismutase, ascorbate peroxidase and glutathione reductase in bean leaves. Plant Physiol. 98, 1222-1227.

Chen, G.X., Asada, K., 1989. Ascorbate peroxidase in tea leaves: occurrence of two isozymes and the difference in their enzymatic and molecular properties. Plant Cell Physiol. 30, 987-998.

Collen, J., Davison, I.R., 1999a. Reactive oxygen metabolism in intertidal Fucus spp. (Phaeophyceae). J. Phycol. 35, 62-69.

Collen, J., Davison, I.R., 1999b. Stress tolerance and reactive oxygen metabolism in the intertidal red seaweeds Mastocarpus stellatus and Chondrus crispus. Plant Cell Environ. 22, 1143-1151.

Collen, J., Jimenez del Rio, M., Garcia-Reina, G., Pedersen, M., 1995. Photosynthetic production of hydrogen peroxide by Ulva rigida C, Ag (Chlorophyta). Planta 196, 225-230.

Collen, J., Pedersen, M., 1996. Production, scavenging and toxicity of hydrogen peroxide in the green seaweed Ulva rigida. Eur. J. Phycol. 31, 265-271. 
Davison, I.R., Pearson, G.A., 1996. Stress tolerance of intertidal seaweeds. J. Phycol. 32, 197-211.

Elstner, E.F., 1982. Annu. Rev. Plant Physiol. 33, 73-96.

Elstner, E.F., 1987. Metabolism of activated oxygen species. In: Davies, D.D. (Ed.), Biochemistry of Plants, vol II. Academic Press, London, pp. 253-315.

Forti, G., Gerola, P., 1977. Inhibition of photosynthesis by azide and cyanide and the role of oxygen in photosynthesis. Plant Physiol. 59, 859-862.

Fourcroy, P., 1999. Iron and oxidative stress in plants. In: Smallwood, M.F., Calvert, C.M., Bowles, D.J. (Eds.), Plant Responses to Environmental Stress. BIOS, Oxford, pp. 51-57.

Foyer, C., Mullineaux, P.M., 1994. Causes of Oxidative Stress and Amelioration of Defence Systems in Plants. CRC Press, Boca Raton.

Foyer, C.H., Rowell, J., Walker, D., 1983. Measurement of ascorbate content of spinach leaf protoplasts and chloroplasts during illumination. Planta 157, 381-392.

Fridovich, I., 1978. The biology of oxygen radicals. Science 201, 875-880.

Fujimoto, K., Ohmura, H., Kaneda, T., 1985. Screening for antioxygenic compounds in marine algae and bromophenols as effective principles in a red alga Polysiphonia urceolata. Bull. Jpn. Soc. Sci. Fish. 51, $1139-1143$.

Glombitza, K.-W., Stoffelen, H., Murawski, U., Bielaczek, J., Egge, H., 1974. Antibiotika aus Algen. Mitt, Bromphenole aus Rhodomelaceae. Planta Med. 25, 105-114.

Goldberg, D.M., Spooner, R.J., 1983. Glutathione reductase. In: Bergmeyer, H.U. (Ed.), Enzymes oxireductases, transferases, vol. 1. VCH, Weinheim, pp. 258-265.

Halliwell, B., 1982. The toxic effects of oxygen on plant tissues. In: Oberley, L.W. (Ed.), Superoxide Dismutase, vol. I. CRC Press, Boca Raton, pp. 89-123.

Halliwell, B., Gutteridge, J.M.C., 1989. Free Radicals in Biology and Medicine Clarendon Press, Oxford.

Hanelt, D., 1998. Capability of dynamic photoinhibition in Arctic marine macroalgae is related to their depth distribution. Mar. Biol. 131, 361-369.

Kaiser, W., 1976. The effect of hydrogen peroxide on CO2 fixation of isolated intact chloroplasts. Biochim. Biophys. Acta 440, 476-482.

Kaiser, W., 1979. Reversible inhibition of the Calvin cycle and activation of oxidative pentose phosphate cycle in isolated chloroplasts by hydrogen peroxide. Planta 145, 377-382.

Karpinski, S., Reynolds, H., Karpinska, B., Wingsle, G., Creissen, G., Mullineaux, P., 1999. The role of hydrogen peroxide and antioxidants in systemic acclimation to photo-oxidative stress in Arabidopsis. In: Smallwood, M.F., Calver, C.M., Bowes, D.J. (Eds.), Plant Responses to Environmental Stress BIOS Scientific Publishers, Oxford (224 pp.).

Kurata, K., Amiya, T., 1980. A new bromophenol from the red Alga Polysiphonia urceolata. Bull. Chem. Soc. Jpn. 53, 2020-2022.

Larson, R., 1988. The antioxidants of higher plants. Phytochemistry 27, 969-978.

Lopez, F., Vansuyt, G., Casse-Delbart, F., Fourcroy, P., 1996. Ascorbate peroxidase activity, not mRNA level is enhanced in salt stressed Raphanus sativus plants. Physiol. Plant. 97, 13-20.

McCord, J.M., Fridovich, I., 1969. Superoxide dismutase: an enzymatic function for erythrocuprein (hemocuprein). J. Biol. Chem. 244, 6049-6055.

McKersie, B.D., Lesham, Y.Y., 1994. Stress and Stress Coping in Cultivated Plants Kluwer Academic Publishing, Dordrecht (260 pp.).

Pastori, G.M., Trippi, V.S., 1993. Antioxidative protection in a drought resistant maize strain during leaf senescence. Physiol. Plant. 87, 227-231.

Paya, M., Halliwell, B., Hoult, J.R.S., 1992. Peroxyl radical scavenging by a series of Coumarins. Free Radic. Res. Commun. 17 (5), 293-298.

Pedersen, M., Collen, J., Abrahamsson, K., Ekdahl, A., 1995. Production of halocarbons from seaweeds: an oxidative stress reaction? Sci. Mar. 60, 257-263.

Polle, A., 1996. Mehler reaction: friend or foe in photosynthesis. Bot. Acta 109, 84-89.

Potterat, O., 1997. Antioxidants and free radical scavengers of natural origin. Curr. Org. Chem. 1, 415-440.

Schreck, S., Dornenburg, H., Knorr, D., 1996. Evaluation of hydrogen peroxide production in tomato (Lycoopersicon esculentum) suspension cultures as a stress reaction to high pressure treatment. Food Biotechnol. $10,163-171$. 
Schriek, R., 2000. Effects of light and temperature on the enzymatic antioxidative defense systems in the Antarctic ice diatom Entemoneis Kufferathii Manguin. Reports on Polar and Manne Research, Bremerhaven, $130 \mathrm{pp}$.

Schöner, S., Krause, G.H., 1990. Protective systems against oxygen species in spinach: response to cold acclimation in excess light. Planta 180, 383-389.

Smirnoff, N., Colombe, S.V., 1988. Drought influences the activity of enzymes of the chloroplast hydrogen peroxide scavenging system. J. Exp. Bot. 39, 1097-1108.

Tanaka, K., Otsubo, T., Kondo, N., 1982. Participation of hydrogen peroxide in the inactivation of Calvin cycle SH enzymes in SO2-fumigated spinach leaves. Plant Cell Physiol. 23, 1009-1018.

Vacha, F., 1995. The role of oxygen in photosynthesis. Photosynthetica 31, 321-334.

Wallin, B., Rosengren, B., Shertzer, H.G., Camejo, G., 1993. Lipoprotein oxidation and measurement of thiobarbithuric acid reacting substances formation in a single microtiter plate: its use for evaluation of antioxidants. Anal. Biochem. 208, 10-15.

Willekens, H., Van Camp, W., Van Montagu, M., Inze, D., Langebartels, C., Sandermann, H., 1994. Ozone, sulphur dioxide, and ultraviolet B have similar effects on mRNA accumulation of antioxidant genes in Nicotiana plumbaginifolia L. Plant Physiol. 106, 1007-1014. 